\title{
Value creation in entrepreneurial education: towards a unified approach
}

\author{
Colin Jones \\ Office of the Advancement of Learning and Teaching, \\ University of Southern Queensland - Springfield Campus, \\ Springfield Central, Australia \\ Kathryn Penaluna \\ Research Innovation and Enterprise Services, University of Wales Trinity Saint David, \\ Carmarthen, UK, and \\ Andy Penaluna \\ International Institute for Creative Entrepreneurial Development, \\ University of Wales Trinity Saint David, Carmarthen, UK
}

\begin{abstract}
Purpose - This paper aims to propose a unified framework for understanding the development and distribution of value within and from enterprise and entrepreneurship education. In doing so, the authors trace the origins of value creation pedagogy back 100 years and reconnect this lost literature to contemporary thinking as to what constitutes value creation pedagogy.

Design/methodology/approach - This conceptual paper identifies specific temporal-specific problems with current thinking in enterprise and entrepreneurship education vis-à-vis who gains the value from value creation pedagogies. To address this identified anomaly, the authors seek to develop a spectrum of value-creating activities/processes applicable to enterprise and entrepreneurship education. The underlying aim of this approach is to provide clarity around who specifically benefits from value creation pedagogies, how and when. Findings - In developing a spectrum of value-creating activities/processes applicable to enterprise and entrepreneurship education, the authors have successfully located all major forms of value creation pedagogies in an iterative manner that caters to the authentic development of value for oneself and others. The proposed model assumes that the creation of authentic value for others should be preceded by the development of specific capabilities in the value creators.

Practical implications - There are important implications that arise for all enterprise and entrepreneurship educators in the discussions presented here. Most importantly, value creation pedagogies should be fueled by the ongoing development of purpose, agency and capability via cultivated reflection.

Originality/value - This paper broadens the notion of what constitutes value creation pedagogy in enterprise and entrepreneurship education. In doing so, the authors elevate the importance of student creative competency development over value creation.
\end{abstract}

Keywords Value creation, Student agency, Value creation pedagogy

Paper type Conceptual paper

\section{Introduction}

This paper considers the process of value creation in enterprise and entrepreneurship education, and asks to whom should any value created be appropriated. Is it the students themselves who should benefit primarily, or is it other stakeholders within and/or external to the ecosystems who surround the delivery of enterprise and entrepreneurship education that should benefit most? These questions are central to the aims and purpose of enterprise and entrepreneurship education and have been stimulated by the recent positioning of

The authors wish to thank Dr Martin Lackéus for his helpful comments and suggestions during the writing of this article.
Entrepreneurial education

Received 18 June 2020

Revised 31 August 2020 Accepted 17 September 2020 
value creation pedagogy (VCP) (Lackéus, 2016, 2020) in enterprise/entrepreneurship education and the definitional stance of the European Commission Joint Research Centre (Bacigalupo et al., 2016; FFE-YE, 2012), where acting upon ideas and opportunities is emphasized, thus assuming that ideas and opportunities spotted by learners are at a stage that are ready to be scrutinized. This assumes that students use and develop valuable entrepreneurial competencies through directly engaging in value creation processes (Mulholland and Turner, 2019), where value is created for other stakeholders, in addition to the value gained from the learning experience by the students themselves. In this context, value creation for others is perceived to be more important than value created by nascent entrepreneurs for themselves, in that value creation for others must occur before additional learning outcomes can be received by the students. It takes the approach that focusing on the needs of others from outset will ultimately lead to "deeper learning of subject specific curricular knowledge and skills among students” (Lackéus, 2019, pp. 206-207).

There is a temptation here to be seduced by the tautology of do students of enterprise and entrepreneurship education develop entrepreneurial competencies through engaging in value creation pedagogies, or do students of enterprise and entrepreneurship education develop entrepreneurial competencies in order to create new forms of value? A temptation we deliberately seek to avoid, instead initially preferring to consider the following questions; what is value creation in the context of enterprise and entrepreneurship education? And, what has been the role of value creation in education more broadly? Our approach is to: (1) isolate the historical role of VCP in education, (2) consider the nature of value creation pedagogies in enterprise and entrepreneurship education and (3) consider the possibility of a spectrum of value creating activities/processes applicable to enterprise and entrepreneurship education. In doing so, we make a contribution to Kuratko and Morris's (2018) recent consideration of the future trajectory of entrepreneurship education. Specifically, prioritizing the needs of students over programs and society through deeper consideration of the potential empowerment and transformative aspects of enterprise and entrepreneurship education. However, before proceeding further, it is useful to contextualize what we mean by enterprise and entrepreneurship education and, what we mean by value creation.

Drawing on the QAA (2018, p. 7) guide for UK Higher Education providers, we define enterprise education as (for credit and extra-curricular) activities focused "the generation and application of ideas, which are set within practical situations during a project or undertaking ... that can be applied across all areas of education and professional life. It combines creativity, originality, initiative, idea generation, design thinking, adaptability and reflexivity with problem identification, problem solving, innovation, expression, communication and practical action". Conversely, we define entrepreneurship education "as the application of enterprise behaviours, attributes and competencies into the creation of cultural, social or economic value. This can, but does not exclusively, lead to venture creation. Entrepreneurship applies to both individuals and groups (teams or organisations), and it refers to value creation in the private, public and third sectors, and in any hybrid combination of the three". As such, while acknowledging the broad overlap between both forms of education, we see enterprise education as broadly applicable to all students and related to lifewide learning (Barnett, 2011) and the development of agency (Bandura, 2006). Alternatively, we view entrepreneurship education more narrowly in its application and directly related to acting upon existing abilities and ideas to create new value (see Jones et al., 2019).

To further foreshadow our eventual conclusions, we see value creation (in a purely educational sense) as being first and foremost concerned with the actions of, and change within, individuals (Bethel, 1989), so not necessarily a byproduct of entrepreneurship education. Nevertheless, in adopting this position, we also accept the potential influence of the individual on the broader environment in terms of creating value for others (Lackéus, 2019). Like Felin and Hesterly (2007) and Amabile (1996), we position value creation as a 
process starting with the characteristics of the individual. It has been stated that value creation is "difference between use and exchange value" as contemplated across "all levels of analysis" (Lepak et al., 2007, p. 190). Where use refers to the potential satisfaction one gains from the use of their (existing and developing) knowledge, skills and/or capabilities, and where exchange refers to what can be obtained through the exchange of one's knowledge, skills and/or capabilities. We view such a definition as being broad enough to encapsulate all five forms of value previously associated with enterprise and entrepreneurship education (i.e. economic, enjoyment, social, harmony and influence; see Lackéus, 2018). With these definitions established, let us proceed to consider the role of value creation in education more generally.

\section{Value creation pedagogy: educational roots and history}

Despite not featuring as yet in the enterprise and entrepreneurship education literature, the VCP of Tsunesaburo Makiguchi (see Bethel, 1989) dates back to the 1920s and is still used to teach social entrepreneurship at several Japanese and American universities today. Makiguchi's seminal works argued that the purpose of education should not align to the needs of society, but rather to the individual needs of students, vis-à-vis their own sense of purpose in life. An admirer of Dewey's ideas, Makiguchi like Dewey (1916) pushed for personal growth to be the main aim of education. Further, much like Whitehead's (1932) push against inert ideas in favor of fewer ideas that are directly relevant to the child's development, Makiguchi believed that education should grow out of the emerging needs of each student's daily life. Such a focus, he believed, would lead to happiness within each student who will use "their creative capabilities both to enhance their own lives to the fullest and to create maximum benefit for their community" (Bethel, 1989, p. 6).

From this perspective, Makiguchi saw the potential for human creativity as a constant, and the transfer of knowledge as a potential obstacle towards aiding the direction of such creativity towards the happiness of each student, and ultimately, to the betterment of society. Just as Dewey had earlier proposed growth as the common denominator of education, Makiguchi proposed a similar role for happiness. Several decades later, Heath (1964) would also position satisfaction in all aspects of one's life as a primary goal of education in creating reasonable adventures (see Jones, 2007). A common concern in all these approaches being that the curriculum was able to be centered around the immediate needs of students rather than merely defaulting to pre-determined general needs of a subject area (see Tyler, 1949). In such a context, we can view value creation as personal and preceding the need to produce (context perceived) economic or social value in society, it is about the developmental growth of individuals. In terms of positioning our thinking on this matter, while we recognize the increasing interest in the entrepreneurship education ecosystem (Belitski and Heron, 2017) and the centrality of education to societal outcomes, we adopt the following position. Where others see entrepreneurship education at the heart of entrepreneurial ecosystems, we remain, first and foremost, focused on students being at the heart of enterprise and entrepreneurship education, a point we will frequently revisit.

From this individual perspective, we may also draw upon the extensive experience of the arts, where creative thinking and action results in value creation, and has been a topic of debate for many generations. Most overtly, this can be evidenced within disciplines related to learning to design, which intrinsically employs creative talent to respond to the needs of others (Hesket et al., 2017). Historically, the discipline of design grew out of the industrial revolution and was deemed to require experiential hands-on approaches, as opposed to the more traditional approaches of learning "about" without the learning as to "how" (Hall, 2016). Design educators, therefore, have extensive experience of learning for innovation, especially when this involves co-creation of value. Notably, short-term goals such as those set by a client or customer are 
only developed later in the learning process, as it is believed that a reliance on using customer preferences from outset impedes learning progression (Dervojeda et al., 2014). In practice, learning to be creative in specially simulated/accelerated learning scenarios precedes the objective testing of the potential value created; the ability is tested before the outcomes are measured against norms and expectations. This is partially because design makes distinctions between iterative/incremental innovation based on known goals, and more radical innovation that is built on visioning skills and insights that extend beyond the already known. Whilst "incremental innovation tries to reach the highest point on the current hill. Radical innovation seeks the (next) highest hill" (Norman and Verganti, 2014, p. 79). This stands in direct opposition to Mishra and Zachary's (2014) entrepreneurial value creation theory, which only consists of two iterative stages and focusses on gaining an entrepreneurial reward.

$P 1$. The provenance of VCP lies beyond the historical and disciplinary boundaries of enterprise and entrepreneurship education; therefore, care must be exercised when applying VCP in the domain of enterprise and entrepreneurship education.

Our position here is that enterprise and entrepreneurship education, while currently embracing value creation pedagogies, should do so with sufficient consideration of value creation more generally in education. Just because definitions of entrepreneurship historically have been centered on the process of value creation (see Kao, 1993) does not mean a fully developed position regarding value creation pedagogies has occurred. Therefore, it is important to understand the nature of value creation pedagogies in enterprise and entrepreneurship education.

\section{Value creation pedagogies and enterprise and entrepreneurship education}

The original works of Lackéus and Middleton (2015) and Mishra and Zachary (2014), and especially the more recent work of Lackéus (2020), promote the idea of venture creation programs (previously referred to as $\mathrm{VCP}$, now VeCP) through the use of value creation pedagogies, (somewhat restrictively) defined in terms of creating "new value creation for others" (Lackéus, 2019, p. 202). In this approach, students use whatever pre-existing/assumed entrepreneurial competencies to create new value for others. In this context, value creation can be considered primarily for the benefit of society first, with students presumably gaining insights "through" their participation (Mishra and Zachary, 2014).

This borrows from the notion of an apprenticeship; however, it is important to point out that in apprenticeships, scenario-based learning practices typically precede customer or client engagement (Lave and Wenger, 1991); therefore, competency development goals precede value creation goals. It is generally understood that systems that focus purely on output goals in apprenticeships compare poorly to those that employ a multi-stakeholder arrangement, where learning is the focus (Mulkeen et al., 2019). It is, therefore, our contention that the sequencing of student development in the value creation model remains unclear, because value for others is at least one of the intended outcomes from outset. Within broader enterprise and entrepreneurship education approaches, a developmental role prior to expecting students to engage in new venture/value creation is more commonplace. A brief review of past-related work is useful at this point.

The 4Cs (conceive, create, capture and critique) value creation approach of Jones (2011) was developed to allow the value creator (i.e. the student) to be the primary beneficiary of the value creation process through the identification and use of individual and/or collective resource profiles (Aldrich, 1999). This approach was closely aligned to the personal development aspects of enterprise education. Alternatively, the traditional textbook-led approaches (e.g. Hisrich et al., 2013) offer students the opportunity to learn about the process and theories of new value creation. Such theoretical approaches have often been brought to 
life through the use of specific teaching methodologies (i.e. Sarasvathy, 2008), techniques (Neck et al., 2014) and/or process models (Aulet, 2013) to enable various combinations of theory, practice and reflection to support within students a capacity for new value creation. education

Notions of value creation in enterprise and entrepreneurship education connect back to the initial idea of creative destruction (Schumpeter, 1942) being closely aligned to the process of value creation/opportunity orientation in the domain of entrepreneurship (Fayolle, 2013). Novel combinations of concepts and resources are innovatively recombined to produce new forms of value that have the potential to improve upon and/or replace past practices, heralding in new ways of doing and/or being that have not been pre-conceived as goals. There is a long association with value creation as a central focus in enterprise and entrepreneurship education. Typically, value creation has been used as the context of student projects through which students develop a greater capacity for self-reliance and enterprising behavior (Gibb, 1993). While value creation is often viewed as a public good, it has also been seen to occur after education has fostered self-agency and a propensity and capability for action (Gustafson, 2009). It is important to note here that regardless of the subjectivity (Lepak et al., 2007) surrounding actual value creation (and value capture), the individual value of such educational experiences can still objectively be measured. Therefore, from Gibb's perspective, value creation for students can occur before and/or after value creation by students. Indeed, as is understood in nature (Liveo, 2013), students can develop significantly through reflecting upon their repeated failure to create any value for others through their projects and through metrics such as the number of ideas generated and their ability to be effectively argued through new links and connections, as is the norm in creative subjects such as art and design (QAA, 2017).

P2. Given that there is often much subjectivity surrounding the creation and capture of value for others, it is logical to accept that enterprise and entrepreneurship education students can create value for themselves, even if they have not yet done so for others.

This would seem central to the role of enterprise and entrepreneurship education at a time when society increasingly is more complex and unpredictable for students (Barnett, 2011), and the demand for more creative thinking and the development of attitudes relating to flexibility and adaptability in learners increase (Komarkova et al., 2015). In this context, it is the reshaping of our students' cognitive abilities, rather than their external landscapes, that matter most. Such restructuring is also observed to occur in learning, where the human brain's capacity to restructure through the acquisition of higher-order structures enables one to become free of one's history (Bruner, 1962). It is in this context that the authors draw on Vygotsky's developmental theory (see Hanfmann and Vakar, 2012) to view value creation within the pedagogical models utilized in enterprise and entrepreneurship education as being first emancipatory, and second, community serving. Such an approach, while consistent with the different (but often interrelated) roles ascribed to both enterprise education and entrepreneurship education (QAA, 2018), is somewhat more problematic when viewed from explicit new venture creation (see Neck and Corbett, 2018) and/or more societal perspectives (Lackéus, 2019). Nevertheless, the widely accepted presence of dialogic relations (Bruyat and Julien, 2001) necessitates that equal attention is given to both the individual (student) and any act of new value creation.

P3. Neither the individual, their development, nor the act of value creation, for oneself or others, should be viewed in isolation, and/or free from the influence of, and/or dependent upon cognitive development.

At present, there is an increasing interest in the development of comprehensive competency frameworks (see Gibson, 2006; Morris et al., 2013; White et al., 2016; Bacigalupo et al., 2016). Therefore, it is beholden upon educators in our domain to use scholarly inquiry to ascertain in 
what different (and/or similar) ways enterprise and entrepreneurship education are able to support higher-order student learning outcomes. It is also important that researchers consider the experiences of history and disciplinary expertise that precedes more recent work in our own and other domains of education.

\section{Contemporary value creation pedagogy}

The presence of VCP in mainstream education is linked more to the original ideas of Tsunesaburo Makiguchi (and his followers) than any pedagogical approach in the domain of enterprise and entrepreneurship education. Makiguchi's Soka education had, as its central aim, the empowering of students in the pursuit of happiness (Goulah, 2010), or value derived from one's relationship to life. Joffee et al. (2009) argue that Soka education is "not education for society, but a society for education", given its concern for an individual's well-being and social justice. A comparative analysis of Soka education with the capabilities approach of Sen (1985) concluded that both approaches were complimentary, focusing on the rights of individuals to create value for themselves and others using freedom and agency (Sherman, 2016). Interestingly, the inclusion of well-being and social justice influenced the recent adoption of Soka education in Kenya public high schools (perhaps as an alternative to enterprise education, often used to prepare students for the challenges of the modern world). Amollo et al. (2018) concluded that VCP in this context had the potential to complement the effectiveness of problem-based learning approaches.

The presence of Soka's VCP outside of the domains of enterprise and entrepreneurship education has potential to create confusion, especially when it is deemed suitable for entire countries to adopt its methods. At present, there is the original VCP of Makiguchi (Bethel, 1989) and the venture creation and VCPs of Lackéus (2019). There also exist other enterprise and entrepreneurship education approaches that are centered on value creation (Mishra and Zachary, 2014; Sarasvathy, 2008; Jones, 2011; Aulet, 2013) and a host of value creation approaches in the fields of science (McWilliam et al., 2008), the creative industries (Hearn et al., 2007) and technology management (Horwitch and Stohr, 2012). Therefore, it would seem logical to consider (1) the extent to which such approaches are complimentary and (2) how these various approaches might be placed upon a value creation spectrum.

\section{Towards a unified value creation pedagogy}

Each of the approaches discussed above employs unique philosophical positions, none of which should be biased in terms of any preferred selective criteria because each approach has elements that are restrictive in their broader use. The original VCP of Makiguchi, now labeled Soka education (Bethel, 1989) is quite limited to the happiness of the individual. The VCP of Lackéus (2019) can be viewed as operating backward from perceived societal value to assumed student value. In between these two philosophically diverse views are a host of approaches (see Sarasvathy, 2008; Jones, 2011; Aulet, 2013) that vary in how the human and social capital of individuals is leveraged to create new value. In Figure 1, an attempt is made to position the nature of these philosophically diverse approaches on a spectrum.

Figure 1.

The VCP spectrum

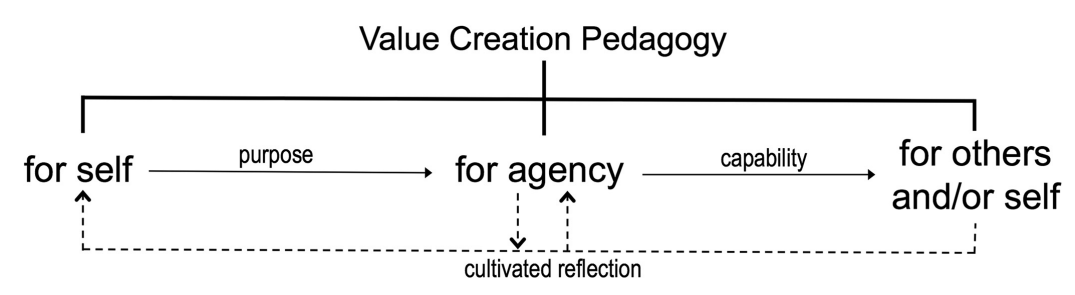


We chose to make a specific impact (Nabi et al., 2017) on enterprise and entrepreneurship education through contemplating the conversion of commonly thought of subject impact measures (e.g. attitudes) into objective impact measures. We contemplate a student's perfect education development in enterprise and entrepreneurship education, acknowledging this process to be rare. In such a world, students would engage in several subjects, all of which bring a different aspect of value creation. Ideally, students would be given an opportunity to explore their sense of self to develop a sense of purpose. Barnett (2007) speaks of the need for students to embrace the challenges of an educational voyage. A process of ontological discomfort through which self-travel is of more importance than intellectual travel. A voyage with others where the value of community is highlighted to ensure support is on hand along the way. Here, Makiguchi's VCP is directly applicable, with individual students able to perceive their life in the context of a nurturing community. In such a context, a student can find happiness and fulfillment that can be directed toward their purpose in life. Importantly, the role of enterprise and entrepreneurship education at this stage is to take the student into unchartered territory, to aim for ontological displacement that ultimately encourages and motivates. Given that in reality (vis-à-vis entrepreneurial outcomes), many are called, but few are chosen (Aldrich and Martinez, 2001), it is logical for enterprise and entrepreneurship education to attempt to impact on the many more so than the few. So, we are positioning VCP as applicable to all students, regardless of their varied future intentions.

Having developed a sense of purpose, students must develop a capacity to act upon such a purpose. Jones et al. (2019) make the case that the development of agency (or a capacity for self-negotiated action) is central to the purpose of enterprise and entrepreneurship education. Assuming that to be reasonable, we can contemplate also the four core properties of human agency as proposed by Bandura (2006). First, humans must demonstrate intentionality (or purpose) and be capable of blending their self-interest with others to advance their own desires; again, the importance of community is important. But, the development of the self (or individuation, as Jung (1921) referred to it) is critical to ensure one's true self can operate effectively inside and outside the collective. Second, the closely related process of forethought paves the way for the student's imagination to play forward their purpose and visualize what might be possible, even when clear goals are not articulated, a necessary pre-condition of authentic purpose. Third, students need to develop the ability to plan their intended action through a process of self-reactiveness. This includes self-assessment of one's current abilities and their assumed potentiality vis-à-vis one's developing purpose. Finally, Bandura notes the importance of self-reflectiveness to enable individuals to exhibit metacognitive abilities associated with reflection. This is perhaps one of the hardest core properties for students to develop when it is also recognized that accurate reflection is more often than not possible (Doris, 2015), though can be encouraged through an understanding of memory types and human cognition (Penaluna, 2019).

Here, at this critical junction in the process of VCP, we argue that great care is required to cultivate appropriate reflection (see Jones, 2019) through which authentic transformative learning (Mezirow, 1978) outcomes are possible. This suggests that the refinement on earlylevel impact indicators (see Jack and Anderson, 1998; Nabi et al., 2017) to address such specific metacognitive learning outcomes is required. As can be seen in Figure 1, the process of reflection serves two distinct purposes. First, it supports the development of one of the core properties of human agency. Second, it feeds back into the individual students' sense of self, providing moments of ontological truth to emerge in which the nature of one's purpose is further shaped. A key factor throughout this entire process is the authentic enrolment of the students' life circumstances, as proposed by Makiguchi over 100 years ago (Bethel, 1989) using different forms of heutagogy (Jones et al., 2014). Consistent with the timeless ideas of Dewey (1913), aligning the educational experience to the direction of the student's own growth should increase both their level of interest and their recognized identity in society. 
When students are free to act on their developing purpose, experiment, explore and experience disappointment and joy (vis-à-vis their naïve expectations), the right conditions to develop specific entrepreneurial capabilities are present. As with more sophisticated hierarchical research into motivational constructs contests (Vallerand, 1997), the intrinsic motivation of creativity and mastery is known to be more powerful than external rewards. Moreover, behavioral science suggests that when extrinsic rewards are the dominant feature, underperformance results (Pink, 2011). At this point in time, and commensurate with the individual's or group's resource profile (Aldrich, 1999), the evolving capability of students set can be further developed through attempting to create value for others. One advantage of the approach championed by Lackéus (2016) is the likelihood of outcomes that are both visible and more readily measurable. Nevertheless, we argue (at this stage of the process) that students need to be capable of producing outcomes worthy of measurement, and that other disciplines are more advanced in developing student preparedness, especially when innovation is required. The current renaissance of discipline-specific competencies for enterprise and entrepreneurship education (Morris et al., 2013; Bacigalupo et al., 2016; White et al.,2016) is indicative of the focus of such capability development. As indicated in Figure 1, during this stage of the process, additional feedback is also potentially generated to (1) support the further development of student agency (and therefore capability) and (2) further shape the student's sense of self (and therefore sense of purpose).

In reality, we accept that students of enterprise and entrepreneurship education rarely experience the breadth of subject offerings to support their full development along the envisaged spectrum; this is a current limitation for all students of entrepreneurship. One can easily imagine the frustration of the student left to contemplate their potential, deprived of an opportunity to act on their purpose in any authentic manner. Just as frustrating would be being required to act on someone else's purpose, without having developed sufficient agency/ capability and motivation to have a sporting chance at success.

To recap, at each position along our proposed VCP spectrum, value creation is possible. Settling for a definition of value creation as the "difference between use and exchange value" (Lepak et al., 2007, p. 190) affords us the ability to view the development of knowledge, skills and/or capabilities as underwriting the value (derived from the education process) that is captured by the developing student. We see this as a critical aspect of the thinking developed here, because then we can also embrace the well-developed thinking of others (see Lackéus, 2019), which perhaps unintentionally restrict value creation in enterprise and entrepreneurship education to acts specifically associated with creating value for others.

In returning to our three propositions, we can make the following comments. We should take additional care when we speak of value creation (proposition 1), given it is not a process solely defined and/or aligned to entrepreneurship. To assume otherwise is to ignore the various other competing agendas in society also related to growth, development and prosperity. Next, accepting that the future of entrepreneurship education is less about starting new businesses and more about empowerment and transformation (Kuratko and Morris, 2018) means staying focused first and foremost on students of enterprise and entrepreneurship education (proposition 2). Finally, the development of impact outcome measures (Nabi et al., 2017) enterprise and entrepreneurship education programs must account for the holistic development of individual students (proposition 3) prior to establishing vicarious claims of success at the new venture and/or societal level.

Extending this logic, we can envisage increased opportunities to integrate enterprise and entrepreneurship education initiatives into other disciplines through embracing value creation as first and foremost being a common process we as humans all experience as our lives develop (proposition 1). Next, we can see opportunities to connect enterprise and entrepreneurship education to multiple societal agendas related to overcoming the challenges inherent to growing up in society, such as anxiety and disadvantage (proposition 2). Finally, 
we see the opportunity to reset how policy makers view enterprise and entrepreneurship education and its potential contributions to society (proposition 3), shifting from an assumed economic focus to a citizenship focus.

\section{Conclusion}

This conceptual paper has positioned a range of accepted learning outcomes germane to both enterprise and entrepreneurship education upon a logical spectrum. In doing so, we make possible a deeper consideration of where and to whom value creation in enterprise and entrepreneurship education should belong and/or benefit. In doing so, we believe we have proposed an approach that balances the interrelated personal development and venture creation orientations that will undoubtedly continue to shape emerging standards in our field of education globally (e.g. QAA, 2018).

This paper, therefore, seeks to unpack the nature of value creation more generally in enterprise and entrepreneurship education to more fully appreciate the nature of similarities and/or differences between value creation processes within the pedagogical approaches utilized in our field of learning, especially when compared to more experienced educational approaches. The authors' motivation was not to identify best practice, but rather to contextualize how and when different value creation approaches might best be used to advance student development and learning. This paper also contributes to contemporary ongoing debates as to the purpose and focus of enterprise and entrepreneurship education (see Lackéus, 2016; Neck and Corbett, 2018; Fayolle, 2018), its place in entrepreneurial ecosystems (Belitski and Heron, 2017) and the trajectory of its future development (Kuratko and Morris, 2018). In stripping back the process of education to the development of purpose, agency, competencies and capabilities, this paper seeks to clarify the types of value creation in enterprise and entrepreneurship education and to illuminate aspects of ontological positioning that may skew or bias an educator's approach. The authors argue that in the absence of such clarity, the domain of enterprise and entrepreneurship education is left aiming for the most obvious of learning outcomes (e.g. entrepreneurial competencies and/or new venture creation), without a fully developed sense of how and why such related value creation should occur.

Finally, there are implications that arise from this paper for policy makers. Currently, the domain of enterprise and entrepreneurship education is a policy darling, capturing the attention of many. However, to fulfill our increasing commitments to society, enterprise and entrepreneurship education must also be capable of meeting Bloom's (1956, p. 27) fundamental requirement that "educational objectives must be related to a psychology of learning. The faculty must distinguish goals that are feasible from goals that are unlikely to be attained in the time available, under the conditions which are possible, with the group of students to be involved." As enterprise and entrepreneurship education spread their institutional coverage, merely claiming we are the discipline of value creation will not suffice, especially as explained here, when other disciplines have a head start. Collectively, the domain must develop a deeper understanding of where and to whom value creation in enterprise and entrepreneurship education should belong and/or benefit and how such value could realistically be created.

\section{References}

Aldrich, H. (1999), Organizations Evolving, Sage Publications, London.

Aldrich, H. and Martinez, M. (2001), "Many are called, but few are chosen”, Entrepreneurship: Theory and Practice, Vol. 25 No. 4, pp. 41-57.

Amabile, T. (1996), Creativity in Context, Westview Press, Boulder, Colorado. 
Amollo, O., Wanjiru, K. and Khavugwi, G. (2018), "Adopting value creating pedagogy and problembased learning in secondary schools in Kenya", World Journal of Educational Research, Vol. 5 No. 3, pp. 269-287.

Aulet, B. (2013), Disciplined Entrepreneurship, John Wiley \& Sons, New Jersey, NJ.

Bacigalupo, M., Kampylis, P., Punie, Y. and Van den Brande, G. (2016), EntreComp: The Entrepreneurship Competence Framework, Publication Office of the European Union, Luxembourg.

Bandura, A. (2006), “Towards a psychology of human agency", Perspectives on Psychological Science, Vol. 1 No. 2, pp. 164-180.

Barnett, R. (2007), A Will to Learn: Being a Student in an Age of Uncertainty, McGraw Hill, New York, NY.

Barnett, R. (2011), "Lifewide education: a new and transformative concept for higher education", in Jackson, N. (Ed.), Learning for a Complex World: A Lifewide Concept of Learning, Education and Personal, Authorhouse, London.

Belitski, M. and Heron, K. (2017), "Expanding entrepreneurship education ecosystems", Journal of Management Development, Vol. 36 No. 2, pp. 163-177.

Bethel, D. (1989), Education for Creative Living: Ideas and Proposals of Tsunesaburo Makiguchi, State University Press, Ames, Iowa.

Bloom, B. (1956), Taxonomy of Educational Objectives: The Classification of Educational Goals, Longmans, Green, New York, NY.

Bruner, J. (1962), On Knowing, Belknap Press, Cambridge.

Bruyat, C. and Julien, P. (2001), "Defining the field of research in entrepreneurship", Journal of Business Venturing, Vol. 16 No. 2, pp. 165-180.

Dervojeda, K., Verzijl, D., Nagtegaal, F., Lengton, M. and Rouwmaat, E. (2014), Design for Innovation: Co-creation Design as a New Way of Value Creation, European Commission, Brussels.

Dewey, J. (1913), Interest and Effort in Education, Houghton Mifflin Company, New York, NY.

Dewey, J. (1916), Democracy and Education, Free Press, New York, NY.

Doris, J. (2015), Talking to Ourselves: Reflection, Ignorance, and Agency, Oxford University Press, London.

Fayolle, A. (2013), "Personal views on the future of entrepreneurship education", Entrepreneurship and Regional Development, Vol. 25 Nos 7/8, pp. 692-701.

Fayolle, A. (2018), A Research Agenda for Entrepreneurship Education, Edward Elgar Publishing, Cheltenham and Northampton, MA.

Felin, T. and Hesterly, W. (2007), "The knowledge-based view, nested heterogeneity, and new value creation: philosophical considerations on the locus of knowledge", Academy of Management Review, Vol. 32 No. 1, pp. 195-218.

FFE-YE (2012), "Impact of entrepreneurship education in Denmark - 2011", in Vestergaard, L., Moberg, K. and Jørgensen, C. (Eds), Odense: The Danish Foundation for Entrepreneurship Young Enterprise, available at: https://eng.ffe-ye.dk/media/202248/impact_of_entrepreneurship _education_in_denmark_2011.pdf (accessed 18 June 2000).

Gibb, A. (1993), "Enterprise culture and education: understanding enterprise education and its links with small business, entrepreneurship and wider educational goals", International Small Business Journal, Vol. 11 No. 3, pp. 11-34.

Gibson, D. (2006), The E Factor, Enterprise HQ, London.

Goulah, J. (2010), "(Harmonious) community life as the goal of education", Schools: Studies in Education, Vol. 7 No. 1, pp. 64-84.

Gustafson, J. (2009), "Entrepreneurship as a liberal art", in West, P., Gatewood, E. and Shaver, K. (Eds), Handbook of University-wide Entrepreneurship Education, Edward Elgar Publishing, Cheltenham and Northampton, MA. 
Hall, P. (2016), Reintegrating Design Education: Lessons from History, Design Research Society, Entrepreneurial Brighton.

Hanfmann, E. and Vakar, G. (2012), Thought and Language, Martino Publishing, Cambridge, education Mansfield.

Hearn, G., Roodhouse, S. and Blakey, J. (2007), "From value chain to value creating ecology: implications for creative industries development policy", International Journal of Cultural Policy, Vol. 13 No. 4, pp. 419-436.

Heath, R. (1964), The Reasonable Adventurer, University of Pittsburgh Press, Pittsburgh.

Hesket, J., Dilnot, C. and Boztepe, S. (2017), Design and the Creation of Value, Bloomsbury Academic, London.

Hisrich, R., Peters, M. and Shepherd, D. (2013), Entrepreneurship, MaGraw-Hill Irwin, New York, NY.

Horwitch, M. and Stohr, E. (2012), "Transforming technology management education: value creationlearning in the early twenty-first century", Journal of Engineering and Technology Management, Vol. 29, pp. 489-507.

Jack, S. and Anderson, A. (1998), "Entrepreneurship education within the condition on entreprenology", Proceedings of the 2nd Enterprise and Learning Conference, University of Aberdeen, Aberdeen, September, pp. 10-11.

Joffee, M., Goulah, J. and Gebert, A. (2009), "Practical implementation of Soka education: a dialogue with Monte Joffee”, Educational Studies, Vol. 45, pp. 181-192.

Jones, C. (2007), "Creating the reasonable adventurer: the co-evolution of student and learning environment", Journal of Small Business and Enterprise Development, Vol. 14 No. 2, pp. 228-240.

Jones, C. (2011), Teaching Entrepreneurship to Undergraduates, Edward Elgar Publishing, Cheltenham and Northampton, MA.

Jones, C. (2019), How to Teach Entrepreneurship, Edward Elgar Publishing, Cheltenham and Northampton, MA.

Jones, C., Matlay, H., Penaluna, K. and Penaluna, A. (2014), "Claiming the future of enterprise education”, Education + Training, Vol. 56 Nos 8/9, pp. 764-775.

Jones, C., Penaluna, K. and Penaluna, A. (2019), "The promise of andragogy, heutagogy and academagogy to enterprise and entrepreneurship education", Education + Training, Vol. 61 No. 9, pp. 1170-1185.

Jung, C. (1921), Personality Types, Bollinger Press, New Jersey, NJ.

Kao, R. (1993), "Defining entrepreneurship: past, present and?", Creativity and Innovation Management, Vol. 2 No. 1, pp. 69-70.

Komarkova, I., Conrads, J. and Collado, A. (2015), Entrepreneurship Competence: An Overview of Existing Concepts, Policies and InitiativesEuropean Commission, Brussels.

Kuratko, D. and Morris, M. (2018), "Examining the future trajectory of entrepreneurship", Journal of Small Business Management, Vol. 56 No. 1, pp. 11-23.

Lackéus, M. (2016), “A 'value' and 'economics' grounded analysis of six value creation based entrepreneurial education initiatives", Proceedings of the 3E ECSB Entrepreneurship Education Conference, Leeds, May 11-13.

Lackéus, M. (2018), "What is value? - a framework for analyzing and facilitating entrepreneurial value creation”, Uniped, Vol. 41 No. 1, pp. 10-28.

Lackéus, M. (2019), "Making enterprise education more relevant through mission creep", in Mulholland, G. and Turner, J. (Eds), Enterprising Education in UK Higher Education: Challenges for Theory and Practice, Routledge, London.

Lackéus, M. (2020), "Comparing the impact of three different experiential approaches to entrepreneurship education", International Journal of Entrepreneurial Behavior and Research, Vol. 26 No. 5, pp. 937-971, doi: 10.1108/IJEBR-04-2018-0236. 
Lackéus, M. and Middleton, K. (2015), "Venture creation programs: bridging entrepreneurship education and technology transfer", Education + Training, Vol. 57 No. 1, pp. 48-73.

Lave, J. and Wenger, E. (1991), Situated Learning: Legitimate Peripheral Participation, Cambridge University Press, Cambridge.

Lepak, D., Smith, K. and Taylor, S. (2007), "Value creation and value capture: a multilevel perspective", Academy of Management Review, Vol. 32 No. 1, pp. 180-194.

Liveo, M. (2013), "Don't bristle at blunders”, Nature, Vol. 497, pp. 309-310.

McWilliam, E., Poronnik, P. and Taylor, P. (2008), "Re-designing science pedagogy: reversing the flight from science", Journal of Science Education and Technology, Vol. 17 No. 3, pp. 226-235.

Mezirow, J. (1978), "Perspective transformation”, Adult Education, Vol. 28 No. 2, pp. 100-110.

Mishra, C. and Zachary, R. (2014), "The theory of entrepreneurial competence", in Mishra, C. and Zachary, R. (Eds), The Theory of Entrepreneurship, Palgrave Macmillan, London.

Morris, M., Webb, J., Fu, J. and Singbal, S. (2013), "A competency-based perspective on entrepreneurship education: conceptual and empirical insights", Journal of Small Business Management, Vol. 51 No. 3, pp. 352-369.

Mulholland, G. and Turner, J. (2019), Enterprising Education in UK Higher Education: Challenges for Theory and Practice, Routledge, London.

Mulken, J., Abdou, H., Leigh, J. and Ward, P. (2019), "Degree and higher level apprenticeships: an empirical investigation of stakeholder perceptions of challenges and opportunities", Studies in Higher Education, Vol. 44 No. 2, pp. 333-346.

Nabi, G., Liñán, F., Fayolle, A., Krueger, N. and Walmsley, A. (2017), "The impact of entrepreneurship education in higher education: a systemic review and research agenda", The Academy of Management Learning and Education, Vol. 16 No. 2, pp. 277-299.

Neck, H. and Corbett, A. (2018), "The scholarship of teaching and learning entrepreneurship", Entrepreneurship Education and Pedagogy, Vol. 1 No. 1, pp. 8-41.

Neck, H., Greene, P. and Brush, C. (2014), Teaching Entrepreneurship: A Practice-Based Approach, Edward Elgar Publishing, Cheltenham and Northampton, MA.

Norman, D. and Verganti, R. (2014), "Incremental and radical innovation: design research vs. technology and meaning change", Design Issues, Vol. 30 No. 1, pp. 78-96.

Penaluna, A. (2019), "Through the lenses of the two I's; implement or innovate", in Kapranos, P. (Ed.), The Interdisciplinary Future of Engineering Education: Breaking Through Boundaries in Teaching and Learning, Routledge, London.

Pink, D. (2011), A Whole New Mind, Cannongate Books, Edinburgh.

QAA (2017), Subject Benchmark Statement: Art and Design, Quality Assurance Agency for Higher Education, Gloucester, available at: https:/www.qaa.ac.uk/docs/qaa/subject-benchmarkstatements/sbs-art-and-design-17.pdf?sfvrsn=71eef781_16 (accessed 17 June 2020).

QAA (2018), Enterprise and Entrepreneurship Education: Guidance for UK Education Providers, Quality Assurance Agency for Higher Education, Gloucester, available at: https://www.qaa.ac. uk/docs/qaas/enhancement-and-development/enterprise-and-entrpreneurship-education-2018. pdf?sfvrsn=15f1f981_8 (accessed 17 June 2020).

Sarasvathy, S. (2008), Effectuation: Elements of Entrepreneurial Expertise, Edward Elgar Publishing, Cheltenham and Northampton, MA.

Schumpeter, J. (1942), Capitalism, Socialism and Democracy, Harper \& Row, New York, NY.

Sen, A. (1985), "Well-being, agency and freedom: the Dewey lectures 1984", The Journal of Philosophy, Vol. 82, pp. 169-221.

Sherman, P. (2016), "Value creating education and the capability approach: a comparative analysis of Soka education's ability to promote well-being and social justice", Cogent Education, Vol. 3, pp. 1-15. 
Tyler, R. (1949), Basic Principles of Curriculum and Instruction, The University of Chicago Press, Entrepreneurial Chicago.

Vallerand, R. (1997), "Towards a hierarchical model of intrinsic and extrinsic motivation", Advances in education Experimental Social Psychology, Vol. 3, pp. 271-360.

White, R., Hertz, G. and Moore, K. (2016), "Competence based education in entrepreneurship: a call to action for the discipline", in Morris, M. and Liguori, E. (Eds), The Annals of Entrepreneurship Education and Pedagogy - 2016, Edward Elgar Publishing, Cheltenham and Northampton, MA.

Whitehead, A. (1932), The Aims of Education and Other Essays, Williams \& Norgate, London.

\section{Corresponding author}

Colin Jones can be contacted at: Colin.Jones@usq.edu.au

For instructions on how to order reprints of this article, please visit our website:

www.emeraldgrouppublishing.com/licensing/reprints.htm

Or contact us for further details: permissions@emeraldinsight.com 